\title{
薬物キャリアーの最前線
}

中川晋作

\section{The Frontiers of Drug Carrier}

\author{
Shinsaku NAKAGAWA \\ Department of Biotechnology and Therapeutics, Graduate School of Pharmaceutical Sciences, \\ Osaka University, 1-6 Yamadaoka, Suita City 565-0871, Japan
}

近年分子生物学の進歩に伴い, 薬物の概念が急速 に変化してきた。これまでの低分子有機化合物に 加えて，プラスミド DNA やアンチセンス核酸, siRNA 等の機能性核酸, サイトカイン等の生理活 性蛋白質や生理活性ペプチド，また抗原蛋白質や抗 原ペプチド等，生体高分子をも薬物として捉えて各 種疾病を治療しようとする次世代先端医療・薬物療 法の開発が進められている。一方，薬物治療の最適 化を目指す Drug delivery system（DDS）に用いら れる方法論は，薬物の分子構造を合成化学的に修飾 して物性や体内動態を改変する「創薬的手法」と, 剤形の工夫によって薬物の体内動態を改善する「創 剂的手法」の 2 つに大別される。 その中で, 生体高 分子を薬物として捉えて医薬品開発を行うに当たつ ての DDS は, 前者の幅広い誘導体展開や化学修飾 といった方法論よりも，むしろ後者の方法論をより 発展させた戦略が有効であると考えられる。すすお ち，近年進展著しいナノテクノロジーを応用し，機 能性に優れた新規薬物送達キャリアーを創製するこ とが，汎用性に優れる DDS 基盤技術の確立につな がるであろう，既に米国ではナノテクノロジーに立 脚した National cancer institute 主導の研究プログ ラム（Cancer Nanotechnology Plan）が基幹プロジ エクトとして採択され，また本邦においても医学・ 工学・薬学など多分野にまたがる府省連携プロジエ クトとして「ナノDDS」をテーマにしたプロジェ クトが展開されている。これら国家プロジェクトの 研究成果によって, 原子操作や高分子物質の自己組
織化などを利用して，従来では全く想像できなかつ た新しい物性・特性を持ったナノ構造体の創製が可 能になってきており，ナノテクノロジーは生体高分 子の DDS キャリアー開発における革新的技術とし て大いに期待されている.

これまでに高分子化学やナノテクノロジーの技術 を駆使し，薬物を安定かつ効率よく保持した上で薬 物徐放化能やターゲティング能等, 様々な DDS 機 能を有する薬物キャリアーの開発が試みられてい る. 本特集では，丸山一雄先生（帝京大・薬）と吉 川友章先生 (阪大院・薬) に新しいタイプのリポソー ムとしてそれぞれバブルリポソームと膜融合リポ ソームの遺伝子導入ベクター並びにワクチンキャリ アーとしての有用性について解説頂いた。また，鄭 周姫先生（阪大産業科学研）にはウイルス法とリポ ソーム法のハイブリッド型としてのバイオナノカプ セルについてご執筆頂いた。ささら落谷孝広先生 （国立がんセンター研）には，アテロコラーゲンを 用い，また市川秀喜先生（神戸学院大・薬）には八 イドロゲルを用い，それぞれ siRNA 及びペプチド の生体内デリバリーについて解説頂いた．最後に田 畑泰彦先生（京大再生研）には，再生医療を中心と した次世代の先端医療を支える機能性薬物キャリ アーについてご執筆頂いた．薬物キャリアーの開発 研究は, 次世代先端医療・薬物療法を展開していく 上で不可欠であり，その研究成果に大きな期待が寄 せられている，今回紹介したわれわれの研究がこの 分野の更なる発展につながれば幸いである. 